\title{
A SZERVEZETI FIGYELEM IRÁNYÍTÁSA KETTŐS KÉPESSÉGÜ SZERVEZETBEN
}

\section{MANAGING ORGANIZATIONAL ATTENTION IN AN AMBIDEXTROUS ORGANIZATION}

Jelen tanulmány egy nagyvállalat kettős képességű szervezetté válásának folyamatát mutatja be. Az informatikai vállalat versenykörnyezetét extrém verseny jellemzi, amelyben a lehetőségek felderítése és gyors kiaknázása létfontosságú képesség. A kutatás a felső és középvezetők közötti együttműködést vizsgálva arra az eredményre jutott, hogy fejlett üzletiintelligencia-rendszerek használatával a vállalat kontrollált stratégiai megújulásra vált képessé. Az automatizált és egyben adatvezérelt folyamatban a vonalbeli és középvezetők befolyása csökken, szerepük passzív lesz. Egy kifinomult döntéstámogató rendszer, gondosan kialakított szervezeti politika és kommunikációs stratégia helyettesítheti a kollektív értelemben vett közös stratégiai sémákat. A kontrollált megújulási stratégia előnye, hogy a szervezet teljes mértékben kamatoztathatja az erősen centralizált formális tervezés és ellenőrzés minden előnyét, miközben a szervezet rugalmassá és kettős képességűvé válik.

Kulcsszavak: felső vezetés, középvezetők, kettős képesség, stratégiai megújulás

This study describes the process of a large company becoming an ambidextrous organization. The competitive landscape of an IT company is characterized by extreme competition, where exploring and quickly exploiting opportunities is a critical capability. Studying the interplay between top and middle management, the results indicate that sophisticated business intelligence systems allowed for the pursuit of controlled strategic renewal. In the automated and data-driven process, the influence of line and middle managers is reduced and their role is passive. A sophisticated decision support system, well-designed organizational policy and communication strategy can replace common strategic schemes in a collective sense. The benefit of a controlled renewal strategy is that the organization can fully reap the benefits of a highly centralized formal design and control, while making the organization resilient and dual.

Keywords: top management, middle management, organizational ambidexterity, strategic renewal

Finanszírozás/Funding:

A szerzők a tanulmány elkészítésével összefüggésben nem részesültek pályázati vagy intézményi támogatásban.

\section{Szerzők/Authors:}

Dr. Hortoványi Lilla, egyetemi docens, Budapesti Corvinus Egyetem (lilla.hortovanyi@uni-corvinus.hu)

Füzes Péter, PhD-hallgató, Budapesti Corvinus Egyetem (peter.fuzes@gmail.com)

Dr. Szabó Zs. Roland, egyetemi docens, Budapesti Corvinus Egyetem (zsoltroland.szabo@uni-corvinus.hu)

A cikk beérkezett: 2019.04.24-én, javítva: 2019.09.05-én, elfogadva: 2019.09.09-én.

This article was received: 24.04.2019, revised: 05.09.2019, accepted: 09.09.2019. 
A nnak ellenére, hogy kutatási területként egyre nagyobb népszerüségnek örvend, sok kutató egyetért abban, hogy még mindig keveset tudunk arról, hogy a vállalatok miként biztosítják jelenlegi és jövőbeli életképességüket (Horváth \& Papp, 2015). A szervezeteknek meg kell újítaniuk magukat ahhoz, hogy megszüntessék meglévő kompetenciáik és a változó versenyfeltételek közötti rést (Floyd \& Lane, 2000). Ez azonban nem könnyü feladat. Empirikus vizsgálatok kimutatták, hogy kevés vállalat képes hosszú távon egyszerre kiaknázni meglévő képességeit, miközben új képességet is elsajátít (Raisch, 2008). Kutatók szerint ez arra vezethető vissza, hogy a szervezetek a többsége - legalábbis rövid távon - abban érdekelt, hogy fókuszálja tevékenységeit (Van Looy et al., 2005). Benner és Tushman (2003) arra a következtetésre jutottak, hogy a jövőbeli lehetőségek feltárása nagyon eltérő szervezeti támogatást igényel, ami a vezetők számára rendkívüli kihívást jelent.

A közelmúltban a tudományos figyelem az egyének és csoportok szerepére összpontosított a kiaknázás és a feltárás kiegyensúlyozásában, például Birkinshaw és Gupta (2012), valamint Turner et al. (2013). O’Reilly és Tushman (2013) arra hívták fel a figyelmet, hogy ennek ellenére még mindig keveset tudunk arról, hogy a szervezetek hogyan segíthetik vagy gátolhatják a stratégiai megújulásra vonatkozó vezetői döntéseket. Barney és Felin (2013) szerint az elemzési egységnek az egyénnek kell lennie, mivel a szervezeti kettős képesség az egyének kollektív cselekedetei alapján jön létre. Jelen kutatás ezért azt vizsgálja, hogy egy multinacionális vállalat nagyszabású stratégiai megújulása sikeres lehet-e extrém versenykörnyezetben, miközben a vonalbeli és a középvezetők csak passzív szerepet töltenek be.

Zimmerman et al. (2015) induktív esettanulmányukban arra a következtetésre jutottak, hogy a felülröl lefelé irányuló megújításoknak alternatívája lehet az alulról felfelé irányuló kezdeményezés, amely során a vonalbeli vagy középvezetői szintről kezdeményezik, illetve befolyásolják a folyamatot. Volberda et al. (2001) és később Volberda (2017) javasolta ezért, hogy a felső szintű perspektívát ki kell egészíteni a középvezetői nézőponttal. Kutatásunkban ezért a felső és középvezetés közötti kölcsönhatás, együttmüködés került a vizsgálódás középpontjába.

A kutatás egy nagyvállalat longitudinális vizsgálatára épül esettanulmányos módszertannal. A globálisan müködő nagyvállalat egy régiójára fókuszálva a stratégiai megújulást követtük nyomon kilenc egymást követő évben. A cég a legmodernebb informatikai megoldások nyújtásával piacvezetö, azonban ebben a szektorban a verseny extrém kihívások elé állítja a felső vezetőket (Kuckertz et al., 2010). Ebben a szektorban a ,versenykörnyezet kiszámíthatatlan, nehezen előre jelezhető változásokkal, ami miatt a győztesek rövid idő alatt vesztesekké válhatnak" (Meyer, 1998, p. 3). Az itt bemutatott eset egyedi abban az értelemben, hogy a megújulást nem az iparág vagy a technológia érettsége és az ezzel járó csökkenő bevételek kényszerítették ki, hanem felsővezetői vízióból ered. A közelmúltbeli tanulmányok (lásd például Patel et al., 2013) megállapították, hogy a csúcstechnológiai iparágakban tevékenykedő vállalatok hajlamosabbak az innovációra és kockázatvállalóbbak is. Ugyanakkor nem minden csúcstechnológiai vállalat bizonyul egyformán jónak stratégiai megújulásban. Ezért fontos, hogy megértsük ezen szervezeti képesség kialakulásának folyamatát, különösen a napjainkban zajló negyedik ipari forradalom idején.

A tanulmány több területen bővíti a szakirodalmat. Elsőként, a korábbi kutatásokkal ellentétben rámutat arra, hogyan irányíthatja a stratégiai megújulást egy erős felsővezetői csapat, miközben a középvezetőket a háttérbe szorítja, a szervezeti ellenállást pedig minimalizálja. Másodszor, bemutatja, hogy a kifinomult üzletiintelligenciarendszerek használata, amelyek naprakész információkat biztosítanak a vezetők számára, hogyan támogatják a rugalmas és gyors alkalmazkodást. A felülről vezérelt, a középvezetőket passzív szerepbe állító, üzletiintelligencia-rendszerekkel támogatott stratégiai megújulás bemutatása újszerü a szakirodalomban. Ezt a megújulási folyamatot az erősen központosított jellege miatt „kontrollált út"-ként írhatjuk le. Harmadszor, a tanulmány hozzájárul a szakirodalom továbbfejlesztéséhez azáltal, hogy feltárja a kettős képesség megvalósítása során felmerülő kihívásokat. A megújulás során egy olyan időszakot azonosítottunk, amikor strukturális szétválasztásra volt szükség az új stratégia piaci hatásának maximalizálása érdekében, miközben a szervezet időt kapott a régi rutinok elfelejtésére. Végezetül, a tanulmány negyedik fő következtetése a kommunikáció kiemelt fontossága a szervezeti tagok mozgósításában egy, az iparágat megújító, így a vállalat jövőjét meghatározó technológiai változás során.

\section{Szakirodalmi áttekintés}

A szervezetek alapvető dilemmája, hogy egyszerre kell biztosítaniuk jelenlegi működésük eredményességét és jövőbeli életképességüket (Teece et al., 1997). Evolucionista megközelítésben a vállalatok a bizonytalanságot tanulással próbálják meg csökkenteni, azaz új rutinok és képességek kifejlesztésével és a vállalat környezetének állandó újraértelmezésével (Kiss, 2005).

A kutatók gyakran utalnak ,stratégiai megújulás”ként a vezetők által végzett olyan tevékenységek folyamatára, tartalmára és kimenetelére, amelyek drasztikusan megváltoztatják a szervezet jövőbeli müködését (Volberda et al., 2001). Ez a kifejezés azon szervezeti jellemzők módosítására vagy cseréjére vonatkozik, amelyek jelentősen befolyásolhatják a szervezet hosszú távú kilátásait (Agarwal \& Helfat, 2009; Szabó, 2017). A stratégiai megújulás magában foglalja a szervezet erőforrásainak és képességeinek áttervezését, új stratégiai célok kijelölését, valamint a versenystratégia és a termékpiac fókuszának módosítását (Burgers \& Jansen, 2008; Guth \& Ginsberg, 1990; Stopford \& Baden-Fuller, 1994).

\section{A stratégiai megújulás és a szervezeti kettős képesség kapcsolata}

A stratégiai megújításnak két fontos tulajdonsága van. Először is mindig változást foglal magában. Másodszor, ez egy folyamat, egy olyan kibontakozó út, amelyben a szervezet célja képességeinek megújítása új tudás és innovatív 
magatartás által (Müller \& Kunisch, 2018). A stratégiai megújulási tanulmányok tipikusan evolúciós perspektívából tekintenek a folyamatra. Elörehaladásának különböző fázisait azonosítják, vizsgálódásaik középpontjában pedig a változást támogató ügynökök (change agents) szerepe és cselekvései állnak. Gulati és Puranam (2009) rámutattak, hogy a nagyobb átalakítások során a szervezetek diszkrét, egymástól jól elkülöníthető formális változásokon mennek keresztül, miközben a szervezet informálisan csak kisebb lépésekben és fokozatosan alkalmazkodik a változásokhoz. Általában a megújulási út dinamikájának elemzésére irányuló tanulmányok a kvalitatív módszereken, például esettanulmányokon alapulnak.

Az empirikus bizonyítékok azt mutatják, hogy egyes szervezetek egyidejűleg képesek szerteágazó tevékenységeket folytatni (Duncan 1976; Gibson \& Birkinshaw, 2004). Ezért képesek a jelenlegi képességeik kiaknázása mellett új, jövőbeli képességek feltárására is. March (1991) értelmezésében a kiaknázás a fegyelmezett problémamegoldás és a hatékonyságra törekvés. Ezzel szemben a felderítés, azon tevékenységek összessége, melyeket a vállalat azért végez, hogy megváltoztassa az útfüggőségét, beleértve a kísérletezést és az innovációt. A kettős képességü szervezetek egyidejüleg folytatják ezeket a tevékenységeket, és képesek szinergikus értékeket megragadni a kettő között (Raisch \& Birkinshaw, 2008). Ahogy azt számos kutatás kimutatta, a szervezeti kettős képességű vállalatok jobb teljesítményt érnek el, mint azok, amelyek az egyik képesség rovására a másikra fókuszálnak (lásd Cembrero \& Sáenz, 2018; Hughes et al., 2018; Lubatkin et al., 2006). Az új képességeket feltáró vállalatok nagyobb eséllyel képesek a túlélésre, s ha jól irányítják a folyamatot, akkor megújítási erőfeszítésükkel befolyásolhatják az egész iparág jövőjét (Christensen \& Overdorf, 2000).

A kutatások azonban azt is kimutatták, hogy meglepöen kevés vállalat képes hosszabb távon megújítani alapvető kompetenciáit (Raisch, 2008). Benner és Tushman (2003) azt találta, hogy ennek oka a feltárás és kiaknázás lényegesen eltérő szervezeti támogatási igénye. Beer és Nohria (2000) szerint a mögöttes ok az, hogy a legtöbb szervezet a kiaknázó tevékenységeket részesíti előnyben. A megszokott rutint kényelmesebbnek találják a felderítéssel járó kockázattal és magasabb költségekkel szemben (Andriopoulos \& Lewis, 2009; Liu \& Leitner, 2012). A szervezeti kultúra ezért kritikus meghatározója a szervezeti kettős képesség kialakulásának (Junni et al., 2015).

A szervezeti kettős képesség kutatásának két fő ága ismert. Az egyik arra a feltételezésre épít, hogy a szervezetek bizonyos konfigurációk elfogadásával kettős képességüvé válnak. Például Raisch (2008) három szervezeti megoldást írt le a kettős képesség strukturális szétválasztásával kapcsolatban. Az első az időbeli szétválasztás, ahol centralizált, majd decentralizált időszakok váltják egymást, így időben egyszer a költséghatékonyság és méretgazdaságosság, máskor az innováció és tanulás kerül elötérbe. A második megoldás a térbeli szétválasztás, amelyet különböző vállalati szintű egységek létrehozásával érnek el. Ekkor egy elkülönített szervezeti egység feladata az innováció, míg a többi egység a kiaknázásra összpontosít. A harma- dik megoldás a párhuzamos struktúrák biztosítása, amely lehetővé teszi a munkavállalók számára a kétféle struktúra közötti mozgást. Ebben az esetben az elsődleges, formális struktúrákat, amelyek a rutinfeladatok elvégzésére szolgálnak olyan hálózati struktúrák egészítik ki, amelyek elég rugalmasak az innovatív tevékenységek támogatásához. E nézet támogatói azonban azt is elismerik, hogy a strukturális szétválasztás koordinációs költségekkel jár.

A második kutatási irány Birkinshaw és Gibson (2004) müvére alapul, amely bevezette a kontextusfüggő kettős képesség fogalmát. A kontextusfüggő kettős képesség nem párhuzamos struktúrák létrehozásával érhető el, hanem olyan folyamatok és rendszerek kiépítésével, amelyben a szervezeti tagok saját döntéseket hozhatnak arról, hogyan oszthatják meg idejüket a kiaknázó és a felderítő tevékenységek között mindennapi munkájuk során. Gibson és Birkinshaw azzal érveltek, hogy a kontextusfüggő kettős képesség akkor jöhet létre, amikor a vezetők támogató szervezeti környezetet alakítanak ki. Ez nem elsősorban karizmatikus vezetéssel, vagy erős kultúrával érhető el, hanem gondosan kiválasztott rendszerek és folyamatok létrehozásával, amelyek együttesen alakítják és vezérlik az egyének viselkedését. A kontextus úgy értelmezhetö, mint olyan adminisztratív mechanizmusok létrehozása, amelyek magukban foglalják az egyértelmü teljesítményelvárásokat, a következetes jutalmakat, valamint szankciókat. Ezen mechanizmusok megerősítik a kívánatos magatartásformákat (Chang \& Hughes, 2012).

A korábbi tanulmányok azonban azt is kimutatták, hogy a szervezeti tagok nem rendelkeznek azonos mértékben a felderítéshez szükséges képességekkel, és ezért a kontextusfüggő kettős képesség nehezen megvalósítható (Hortoványi, 2010; Venkataraman, 1997).

A kutatások kimutatták, hogy a technológiák vagy a piaci igények változásai gyakran ösztönzik a felső vezetőket, hogy túlmutassanak a domináns cselekvési logikán, azaz a kiaknázáson (cf. Demeter \& Losonci, 2019; Ren \& Guo, 2011; Nonaka, 1994). Dinamikus környezetben Sidhu et al. (2007) megállapította, hogy létkérdés a nem helyi tudáskeresési magatartás (azaz a feltárás), ami alapján úgy gondoljuk, hogy extrém versenykörnyezetben a vezetőkre nehezedő innovációs nyomás sokkal jelentősebb, mint a lassan változó iparágak esetében.

\section{A középvezetés szerepe a megújulási folyamatban}

A felső vezetéshez (TMT) a vezérigazgató és más szenior vezetők tartoznak, akik az alelnök szintjén vagy felette állnak. A felső vezetők kulcsszerepet játszanak a cég stratégiai orientációjában (Hambrick \& Mason, 1984), így a stratégiai megújításban is. Raes és szerzőtársai szerint azonban még mindig meglepően keveset tudunk a felső és középvezetés viszonyáról a kettős képesség kialakításában, illetve ennek a két szint szerepéről a tevékenységek közötti összehangolás során (Raes et al., 2011).

A középmenedzsment kifejezés a felső vezetők alatt található vezetői szintre utal (lásd pl. Dutton \& Ashford, 1993; Uyterhoven, 1972; Wooldridge et al., 2008). A középvezetés megkülönböztető jellemzője azonban nem az, hogy hol szerepelnek a szervezeti diagramban, hanem a 
szerepük a stratégia napi tevékenységekre való lefordításában mutatkozik meg (Wickenberg, 2013). Nonaka (1994) azzal érvelt, hogy egyedülálló helyzetük miatt a középvezetők befolyásolhatják a stratégiai folyamatot azáltal, hogy a szervezet felső és alsó szintjeit összekötik, az információ rajtuk keresztül áramlik. Támogatásuk megnyerése ezért kiemelkedően fontos egy megújulási folyamatban (Burgess et al., 2015). A középvezetés ezért egy szükséges megfigyelési pont a képességek építésével és megújításával kapcsolatos szervezeti folyamat tanulmányozására (Vuori \& Huy, 2016; Wooldridge et al., 2008).

Továbbá, a középvezetők fontos szerepet játszanak a vállalat szervezeti egységei közötti horizontális kapcsolatok kialakításában és fenntartásában is, mint például a gyártás, a marketing és az értékesítés között, ami elengedhetetlen a sikeres múködéshez (Taylor \& Helfat, 2009).

A középvezetői szint vizsgálata ezért nem is újkeletü, az széles körü tudományos figyelmet kapott a stratégia kialakítása és megvalósítása terén (lásd Balogun \& Johnson, 2004; Burgelman et al., 2018; Floyd \& Wooldridge, 1992; Raes et al., 2011). Wickenberg (2013) rámutatott, hogy a középvezetők hajlamosak arra, hogy a szervezeti stratégia megvalósításában opportunista módon járjanak el. Elöször is, bizonyos mértékig hajlamosak lehetnek a jelentések torzítására a sikerek eltúlzásával és a hibák elfedésével. Fontos információkat rejthetnek el annak érdekében, hogy a felső vezetés figyelmét bizonyos, általuk preferált kérdésekre irányítsák (Dutton \& Ashford, 1993). Másodszor, amennyiben a felső vezetés által támogatott stratégia népszerütlen a középvezetők körében, akkor érdekeltek lehetnek a végrehajtás hátráltatásában. Guth és MacMillan (1986) megjegyezte, hogy a középvezetés aktívan is ellenállhat, mint például nyílt fellépés megbeszéléseken, más szervezeti tagokkal koalícióépítés annak érdekében, hogy megakadályozzák a stratégia megvalósítását. Lehet, hogy szándékosan „blokkolják” a megvalósítást annak érdekében, hogy bebizonyítsák, a választott stratégia nem volt jó döntés. Passzív ellenállás sem ritka, mint például a végrehajtás alacsony prioritása, ami szükségtelen késedelmet eredményez, és a várt eredményeket ellehetetleníti. Ezek mind súlyosan veszélyeztethetik a stratégia megvalósítását, valamint a várt eredmények minőségét (Graham, 1986). Következésképp, a középvezetők strukturális pozíciója miatt hatékonyan megváltoztathatják a cég stratégiai irányát (Burgelman, 1983; Hornsby et al., 2002; Zimmermann et al., 2018).

Összességében elmondható, hogy a kutatók egyetértenek abban, hogy a felső- és középvezetők hatalmi viszonyai között átrendeződés van. A felső vezetés gyakorlatilag hatalmát részben elveszíti, mikor csökken a szervezet cselekvésére vonatkozó tényleges befolyása (Wickenberg, 2013), s ezért a középvezetői elkötelezettség kritikus elöfeltétele a stratégia megvalósításának (Guth \& MacMillan, 1986). Volberda és szerzőtársai (2001) megvizsgálták a középvezetők bevonását nagyvállalatok stratégiai megújulása során, vizsgálódásuk középpontjában pedig a felső vezetők és középvezetők között viszony mellett a külső környezet észlelése állt. Azt találták, hogy extrém versenykörnyezetben ('hypercompetitive') a középvezetői szint bevonása kulcsfontosságú a stratégiai megújulás sikeres végrehajtásához. Ocasio és Joseph (2005) hasonló következtetésre jutottak, és azt javasolják, hogy a stratégiai megújulás egy irányított evolúciós folyamat legyen, amelyben az alulról felfelé irányuló változtatási törekvések is teret kapnak, a középvezetőket pedig a stratégia kialakításába bevonják.

Ezzel szemben más tanulmányok rámutattak arra, hogy vannak formalizált rutinok és eljárások, amelyeket a felső vezetők használhatnak a szervezeti tevékenységek fenntartására vagy épp megváltoztatására (Ren \& Guo, 2011; Simons, 1987). A szervezeti teljesítmény átfogó mérése érdekében, az operatív müködés, valamint a fontos vezetői döntések támogatásához a vállalat egyre nagyobb mértékben alkalmazhat intelligens üzleti rendszereket (Sharda et al., 2014). Khandwalla (1972) azzal érvelt, hogy minél nagyobb a verseny, annál nagyobb szükség van az ellenőrzésre, és annál nagyobb az előnye a kifinomult irányítási rendszerek bevezetésének, s ez különösen igaz intenzív versenykörnyezetben. Véleménye szerint, amikor a verseny középpontjában innovatív termék áll, akkor az bonyolult és igen összetett szervezeti struktúra kialakítását követeli meg. Ekkor az általános müködés magas szintủ integrációt és koordinációt igényel, a szofisztikált üzleti rendszerek ugyanakkor ezt az integrációt nagymértékben támogatják. A gyakorlatban ezek a menedzsmentkontroll-eszközök rendkívül hatékonyan használhatók, rajtuk keresztül a vezetők a vállalati szintü teljesítménynormákat és szabványokat hozhatnak létre és érvényesíthetnek. Simons (1994) jóval korábbi munkája során hasonló következtetésre jutott, azaz a kontrollrendszerek fontos szerepet játszhatnak mind az apróbb lépésekben történő evolúciós, mind a forradalmi változások megvalósításában.

McCarthy és Gordon (2011) kimutatták, hogy a vállalati szintű irányítási rendszerek elősegíthetik a kettős képesség kialakítását. Például a visszajelző kontrollrendszerek, amelyek az esemény utáni információkra támaszkodnak a problémák kijavításával a szervezet kiaknázási képességét erősítik. Ezzel ellentétben az „előremutató” vezérlőrendszerek összegyűjtik az esemény előtti információkat, hogy elöre jelezzék a jövőbeli trendeket és eseményeket, valamint azok hatásait, mielőtt még bármilyen változás bekövetkezne (például a keresletben). Ez az információ segíti a szervezeteket abban, hogy részt vegyenek a ,felderítő tevékenységekben és kéthurkos tanulásban, amire az egyéneknek és szervezeteknek szükségük van a meglévő képességeik radikális átgondolása és megváltoztatása érdekében" (McCarthy \& Gordon, 2011, p. 244).

Szerzők előfeltevése volt, hogy bár e rendszerek müködtetése nagyfokú figyelmet követel meg a felső vezetőktől (például az adatok gyakori és rendszeres értelmezését), lehetővé teszik a felső vezetők számára, hogy visszanyerjék a szervezet tevékenységeire gyakorolt befolyásuk (Szukits, 2017). Ezért véleményünk szerint a vezetői irányítási rendszerek mélyreható hatást gyakorolnak a szervezeti kettős képesség fejlődésére. 


\section{A kimeneti környezet szerepe a stratégiai megújulásban}

A szakirodalom azt sugallja, hogy a hatékony alkalmazkodáshoz a vezetőknek meg kell vizsgálniuk a belső és külső környezetüket. D’Aveni és MacMillan (1990) a felső vezetők figyelmét tanulmányozták sikeres és sikertelen vállalatokban és arra a következtetésre jutottak, hogy a sikeres cégek felső vezetői egyenlő figyelmet fordítottak a belső és külső környezetre, illetve nagyobb figyelmet fordítottak a kimeneti környezetre, mint az input környezetre. Ezzel szemben a sikertelen cégek vezetői hajlamosak voltak figyelmen kívül hagyni a kimeneti tényezőket, és nagyobb figyelmet fordítottak az input tényezőkre, továbbá a belső környezetre. Ezért nem tudták vállalataikat alkalmazkodásra ösztönözni. E cégek kudarca pedig a felsővezetői figyelem megosztásával is magyarázható. Kutatásuk azt igazolta, hogy a sikeres cégek nagyobb figyelmet fordítanak a kimeneti környezetre, mert a legfontosabb kritikus sikertényezők a kimenethez kapcsolódnak: az ügyfél igényei és a termék életciklusa (D'Aveni \& MacMillan, 1990).

A kutatások azt is kimutatták, hogy a piac befutott vezető vállalatai új belépők áldozatául eshetnek, amikor egy feltörekvő technológia, egy romboló innováció megbontja az iparági egyensúlyt (Forbes \& Kirsch, 2011). Az infokommunikációs szektorban ez nem ritka jelenség. Számos olyan vállalatot sorolhatunk fel, amelyek fénykorukban piacvezetőknek számítottak, mára azonban eltüntek, s kudarcuk a bomlasztó (diszruptív) innovációra vezethető vissza (Bőgel, 2008). A bomlasztó innovációk a piac alsó végén, vagy a fogyasztásból kiszorult ügyfelek igényeire és problémáira adnak elsőként megoldást (Christensen et al., 1997), amely alapjaiban alakítja át magát a piacot, a kimeneti környezetet. Egyrészt magán a szektoron belül, amikor az új kombinációk (termékek és szolgáltatások) kiszorítják a régieket; másrészt a szektor újdonságai és más szektorok termékei, szolgáltatásai között, amikor például egy infokommunikációs termék kiszorít egy egészen másfajta terméket vagy vállalkozást (Bőgel, 2008).

Összességében tehát a versenyképesség megőrzése érdekében a feltörekvő iparágak kihívást jelenthetnek a meglévő szervezetek számára, hogy az alaptevékenységükről egy teljesen új, független vagy minimálisan kapcsolódó technológiára váltsanak. A napjainkban zajló digitális transzformáció valamennyi iparágra hatással van, az ügyfelek igényeinek és keresletének változása, illetve a feltörekvő technológiák miatt a vezetők figyelmét a jövő felderítésére is ki kell terjeszteni (Csedő, Zavarkó, \& Sára, 2019; Horváth, 2019; Bower \& Christensen, 1996; Harrigan, 1980).

\section{A szervezeti figyelem szerepe a stratégiai megújulásban}

A szervezeti figyelem nézete ('Attention Based View') tudományterület azzal foglalkozik, hogy a szervezeti figyelem hogyan alakítja a szervezeti alkalmazkodást (Ocasio, 2011). A szervezet magatartását alapvetően az határozza meg, hogy mi kerül a döntéshozók figyelmének a középpontjába (Wei et al., 2014). A stratégia a szervezeti figyelem mintáján alakul ki, amelyet egy bizonyos kérdéskör (pl. problémák, lehetőségek és fenyegetések) és azokra adott válaszok (például erőforrás-allokációs minta, folyamatok és rutinok) alakítanak ki. A vállalat figyelme pedig egy korlátos erőforrás, amely egyidejüleg csak egy viszonylag kis számú tényezőre allokálható (Ocasio, 1997; March, 1991).

Dutton és Ashford (1993) szerint egyetlen egy környezeti tényező sem stratégiai jellegü. Akkor válik azzá, amikor a felső vezetők úgy vélik, hogy fontos és hatással van a szervezeti teljesítményre. A szervezetifigyelem-alapú (ABV) kutatók azt hangsúlyozzák, hogy a felső vezetők a szervezeti figyelem irányításával gyakorolhatják hatalmukat, méghozzá gondosan kialakított kommunikációjukon keresztül (Jansen, 2004; Müller \& Kunisch, 2018; Ross \& Nisbett, 1991; Yu et al., 2005). A kommunikáció tartalma lehetővé teszi a szervezeti tagok számára, hogy a stratégiai kérdésekben, kezdeményezésekben és tevékenységekben bekövetkező változásokra felfigyeljenek és azokkal összhangban cselekedjenek (pl. Kim et al., 2016).

Épp ezért a stratégiai megújulás során döntő fontosságú a szervezeti szókincs megváltoztatása (Nigam \& Ocasio, 2010). A hagyományos szervezeti gondolkodás megújítása érdekében új szavakat és fogalmakat kell bevezetni és elterjeszteni (Kotter, 1995) a szervezeti tagok gondolkodásának és cselekedeteinek formálására, valamint bizonyos cselekvésekre való mozgósítására, továbbá sürgősségük, illetve halaszthatatlanságuk fokozására (Rouhani et al., 2012). Például változó intézményi környezetben az Intel új szókincset hozott létre, amely ,iparági fejlődést elömozdító"-ként definiálta a vállalatot (Ocasio et al., 2018, p. 161). A változásvezetés szempontjából ez azért jelentős, mert általuk csökkenthető a szervezet ellenállása is. Például a kiszámíthatatlan, nem rutinszerü események fenyegető jellegének közlése a változás sürgősségét idézi elő, s egyben egyértelmű üzenetet ad arról is, hogy a korábbi rutin a továbbiakban már nem müködik (Kotter, 1995; Taylor \& Helfat, 2009).

A kommunikáció tehát a vezetők kezében igen hatékony és fontos eszköz, mivel általa bizonyos jelentések felerősíthetők, asszociációk elindíthatók, s így a szervezeti figyelem egy bizonyos problémakörre vagy feladatra összpontosul. Fontos megjegyezni, hogy a környezet bizonyos aspektusait a felső vezetők ki is zárhatják a szervezeti valóságból azáltal, hogy azokról nem vesznek tudomást, s nem kommunikálnak róluk (Ocasio \& Joseph, 2005).

Ren és Guo (2011) szerint a középvezetők nemcsak passzív címzettjei a felső vezetés figyelmeztető jelzéseinek. Mint arra korábban már utaltunk, strukturális elhelyezkedésük miatt képesek befolyásolni a szervezet alsóbb szinteken lévő alkalmazottait, valamint a szervezeti müködést is, és ezáltal a változás szempontjából támogatásuk kritikus (Sine \& David, 2003).

Ugyanakkor a fenyegetés-merevség elmélettel foglalkozó kutatók azt találták, hogy fenyegető helyzetben a felső vezetők hatékonyan tudják csökkenteni a szervezeti tagok részvételre, bevonásra vonatkozó igényét és ezáltal képesek központosítani a döntéshozatalt. Staw és szerzőtársai (1981) például megjegyezték, hogy amikor egy fenyegetést egy külső forrásnak tulajdonítanak, és úgy gondolják, hogy a szervezet sikeresen képes megfelelni a fenyegetésnek, akkor a szervezeti tagok között megnövekszik a kohézió, az 
összetartás, s ezáltal a felső vezetők nagyobb támogatást élveznek. A szervezet tagjai konszenzusra törekednek és támogatják a meglévő vezetés politikáját, elképzeléseit.

Álláspontunk szerint a bomlasztó innovációk komoly külső fenyegetést jelenthetnek a piacvezető vállalatok számára. Ezek megragadásával a felsővezetői kommunikációban a szervezet tagjainak figyelmét egy lehetséges külső fenyegetés sikeres leküzdésére összpontosíthatja, ami által jelentős szervezeti támogatást tud kiváltani. A fenyegetés kommunikációjával végső soron csökkentheti a középvezetés részvételi igényét miközben növeli a szervezeti támogatást.

A szervezeti figyelmet gyakran a hivatalos formájú kommunikációval mérjük, mint például a részvényeseknek küldött levelek, az igazgatótanácsok jegyzőkönyvei, az ülések vagy az informális események megfigyelése (Tuggle et al., 2010; Yu et al., 2005). A kommunikáció különböző formáinak elemzése, beleértve az írásbeli és szóbeli nyelvet, retrospektív térképet adhat a vállalat stratégiájának formálódásáról (Yadav et al., 2007). Az írott kommunikáció tartalmi elemzése is fontos eszköz lehet a szervezeti valóság rekonstrukciójában (Holsti, 1969). Ezért úgy gondoljuk, a szervezeti figyelem hosszirányú vizsgálata segíthet abban, hogy jobban megértsük a stratégiai megújulás folyamatát.

\section{Módszertan}

Tanulmányunkban egy Fortune 500 vállalat stratégiai megújulási útját tanulmányoztuk az elmúlt kilenc évben esettanulmányos módszertannal, Jarzabkowski és szerzőtársai ajánlását követve (2007), mert így lehetőségünk volt felmérni hogyan és miért kapcsolódnak az egyes tevékenységek a stratégiai eredményekhez.

\section{A vizsgált vállalat bemutatása}

A vizsgált vállalat egy amerikai központú, több mint 140 ezer alkalmazottat foglalkoztató globális cég, az üzleti informatikai megoldások piacának egyik vezetője.

A vállalat 2000-ben konszolidálta globális tevékenységét, versenyképessége növelése érdekében (Gelei \& Jámbor, 2018). Ezzel egyidőben az anyavállalati központba került az a központosított informatikai rendszer, amely a cégadatok ,egyetlen igazságforrásává” vált, és megbízható, naprakész információkat szolgáltatott a felső vezetés számára. Ahogy a felső vezetés egyik tagja nyilatkozta:

„Az általunk forgalmazott technológiát használjuk. [A múltban] táblázatokkal és PowerPoint-okkal jártunk a megbeszélésekre, de senki nem volt szinkronban egymással; mindannyiunknak volt egy saját verziója. Most nem számít, hogy hol vagyok, ki vagyok, mindenki ugyanazokat az adatokat látja."

Egy 2006-os interjúban a vezérigazgató egyértelmüen kifejtette, hogy az informatikai rendszerek egységesítését szervezeti kérdésnek tekinti, nem pedig technológiai jellegünek. Olyan struktúrát akart létrehozni, ahol az utasítások egyértelmüen eljutnak a hierarchia valamennyi szintjére, megvalósításuk pedig ellenőrizhető.

2010-re a vállalat rendkívül jövedelmezően müködött a globális üzleti szoftverek piacán, központi szervezeti felépítéssel és döntéshozatallal. Ekkor egy új technológiai trend, a felhőalapú számítástechnika jelent meg, amely akkor még nem jelentett potenciális veszélyt a vállalat jövőjére. Mégis, a jövőbeni piaci változásokat előre vetítve, a felső vezetés egy jelentős stratégiai váltásról döntött, a hagyományos üzletágról a felhőalapú számítástechnikát jelölte ki a stratégiai megújulásának céljává.

\section{Az üzleti környezet bemutatása}

A vállalatok hagyományosan saját informatikai rendszereket építettek ki müködésük támogatására, amihez hardvereket (szervereket és tárhelyeket) és szoftverkomponenseket vásároltak vagy fejlesztettek ki. Az informatikai rendszereket általában a fogyasztó telephelyén alakították ki, ezért az ilyen rendszereket 'on-premise' modellnek nevezik (Füzes et al., 2018). Az utóbbi évtizedben azonban bomlasztó innovációként megjelent a felhőalapú számítástechnika (Sultan \& van de Bunt-Kokhuis, 2012; Sultan, 2013). Az ügyfeleknek a továbbiakban nincs szükségük saját informatikai rendszerre, hanem igénybe vehetik azt, mint szolgáltatást (Spilák \& Kosztyán, 2019; Mell \& Grance, 2011). Az új modellben, a felhasználók (vállalatok és magánfelhasználók egyaránt) a felhőszolgáltatók előfizetőivé válnak (Marston et al., 2011).

A Statista jelentése szerint 2012-ben a nyilvános felhöalapú számítástechnikai szolgáltatások világméretű bevétele a vállalati szoftverbevételek csupán 9,3\%-át tette ki, ami még nem befolyásolta jelentősen a piacot. Azonban ez az arány 2017-re 41,7\%-ra emelkedett, és 2019 végére az emelkedés $58,7 \%$-ig várható. A nyilvános felhőszolgáltatás piacmérete összemérhetővé vált a vállalatiszoftver-piaccal: amíg a hagyományos vállalati szoftverek piaca 2012 és 2019 között várhatóan 54\%-kal nő, addig a nyilvános felhőszolgáltatások piaca ugyanezen időszakban $880 \%$-kal bővül (Statista, 2018).

\section{Adatgyüjtés és elemzés}

A kutatási kérdés megválaszolása érdekében a kutatók félig strukturált egyéni interjúkon, dokumentumelemzésen és megfigyelésen alapuló feltáró kutatást végeztek.

Cuervo-Cazurra és szerzőtársai (2017) szerint a komplex szervezetekkel kapcsolatos kutatások nem foglalkoznak az egyes régiókban található leányvállalatokkal, amelyek jellemzően egy adott régióban versenyeznek, nem pedig globálisan. Például az EU-ban lévő leányvállalatok elsősorban más európai vállalkozásokkal kereskednek és versenyeznek, míg az észak-amerikai üzleti egységek általában észak-amerikaiakkal. Ezzel a javaslattal összhangban, és a kutatás mérhetőségének megőrzése érdekében a mélyinterjúkat a kelet- és közép-európai, a közel-keleti és afrikai régióra (ECEMEA) terjesztettük ki. Ez egy földrajzilag kiterjedt és nagyon sokrétü régió, amely fejlödő országokat is tartalmaz, ahol az on-premise megoldások iránti kereslet a vizsgált kilenc év során még mindig növekedett, ezért ez az üzleti terület kifejezetten jövedelmezö, $\mathrm{s}$ a felhőalapú technológiába való áttérés radikális és kockázatos stratégiai váltásként értékelhető.

Elsődleges adatforrásként a vállalat különböző szintjein dolgozó 19 alkalmazottal folytattunk félig strukturált mélyinterjúkat 2016-2018 között. Az adatgyüjtés során többszintü megközelítést alkalmaztunk annak érdekében, hogy jobban megismerjük a vállalat különböző vezetői szintjeinek állás- 
pontját. Az interjúk a válaszadók munkahelyén személyesen, videokonferencián vagy telefonkonferencián keresztül zajlottak, és 90 és 120 percig tartottak. A video- és telefonkonferenciára azért volt szükség, mert a vizsgált régió földrajzi kiterjedtsége miatt az interjúalanyok jelentős részével az interjú készítői nem tudtak személyesen találkozni.

Másodlagos adatforrásként a vezérigazgatók (CEO) és az igazgatóság elnöke által 2009 és 2018 tavaszi időszakban adott 11 nyilvános beszédet elemeztük, amelyek nyilvános archívumban elérhetőek. Szintén elemeztük a vállalat 2009 és 2018 között publikált éves jelentéseit és sajtóbejelentéseit.

A vállalat etikai és üzleti magatartási kódexe alapján a felső vezetők közé az igazgatóság elnökét, a vezérigazgatót és a szenior alelnököt (Senior Vice President) soroltuk be. Az alelnököket (Vice President), az igazgatókat, a menedzsereket és az elsővonalbeli kereskedelmi vezetőket (sales account manager) középvezetőknek minősítettük. Az interjúalanyokat több üzletágból választottuk az alábbi területekröl: értékesítés, üzleti fejlesztés, iparági szakértők, pénzügy és tanácsadás. Mindegyikük gyakori interakcióban állt az ügyfelekkel, az üzleti partnerekkel, a munkatársaikkal és a müködési területtel. Az interjúalanyok egyötöde a felső vezetés tagja, a többi pedig középvezető. Az 1. táblázat az interjúalanyok vezetői szintű megoszlását mutatja.

1. táblázat Az interjúalanyok és szervezeti pozícióinak áttekintése

\begin{tabular}{|lc|}
\hline Pozíció & $\begin{array}{c}\text { Interjúalanyok } \\
\text { száma }\end{array}$ \\
\hline \multicolumn{1}{|c|}{ Felsővezetői szint } \\
\hline $\begin{array}{l}\text { Vezérigazgató, az igazgatóság } \\
\text { elnöke }\end{array}$ & $\begin{array}{c}\text { 3 (másodlagos } \\
\text { adatforrásból) }\end{array}$ \\
\hline Szenior alelnök (értékesítés) & 2 \\
\hline \multicolumn{2}{|c|}{ 'ónetői szint } \\
\hline $\begin{array}{l}\text { Alelnök (értékesítés, ügyfelek } \\
\text { sikeressége) }\end{array}$ & 4 \\
\hline $\begin{array}{l}\text { Igazgató (értékesítés, üzleti } \\
\text { fejlesztés, tanácsadás, pénzügy) }\end{array}$ & 8 \\
\hline $\begin{array}{l}\text { Értékesítési csapat (értékesítési } \\
\text { vezető, sales account menedzser) }\end{array}$ & 5 \\
\hline
\end{tabular}

Az interjúk olyan kérdésekkel kezdődtek, amelyekkel az interjúalany hátterét és szerepét vizsgáltuk, majd kérdéseket tettünk fel a megújulási út kibontakozásával kapcsolatban. Az interjúprotokollok olyan félig strukturált kérdéseket tartalmaztak, mint például: ,Írja le a felhőalapú számítástechnika módját; hogyan érintette a csapatát a felhő bevezetése; hogyan látja a szerepük bevezetés során?” A kérdések célja a vállalat megújításában résztvevők nézeteinek, attitüdjeinek és érzéseinek feltárása volt. Az adatok elemzése során a történeteket időrendi sorrendbe rendeztük, meghatározva a kulcsfontosságú szempontokat és a tematikus elemzést. Az interjúkat az NVivo 11 számítógéppel támogatott szövegelemző szoftver segítségével elemeztük.

Az így kapott eredményeink ellenőrzéséhez, illetve bővítéséhez megfigyeléseket is tettünk fontos eseményeken (pl. éves vállalati találkozókon) és másodlagos adatokat is gyüjtöttünk a vállalat 2009-től 2018-ig tartó éves jelenté- seiből és a cég sajtóközleményeiből. A nyilvános beszédeket, jelentéseket és sajtóközleményeket, valamint egyéb kommunikációs forrásokat szövegekké alakítottuk át, majd automatizált szövegelemzéssel szintén feldolgoztuk.

Ez a megközelítés összhangban van a korábbi kutatásokkal, amelyek arra utalnak, hogy a hivatalos dokumentumok, mint például az igazgatótanács jegyzőkönyvei vagy informális események megfigyelése utólagos térképet adhat a felső vezetés retorikai taktikájáról és stratégiai menetrendjéről (Yadav et al., 2007). A kommunikáció különböző formáinak elemzése, beleértve az írásbeli és szóbeli kommunikációt is segített a stratégia megvalósítása során hogyan mozgósította a felső vezetés a szervezeti tagokat.

\section{A longitudinális kutatás következtetései A szervezeti figyelem alakulása}

A tartalomelemzés megerösítette, hogy a vállalati stratégia 2009-ben a vállalat vezető pozíciójának megörzéséről szólt a hagyományos (on-premise) szoftveriparban. Nem volt arra utaló jel, hogy a felhőalapú számítástechnika, a felső vezetés radarján lett volna. Az on-premise üzletágba vetett bizalmat 2009-ben a vezérigazgató egyik nyilatkozatai is igazolja:

"Hogy tönkre fog-e tenni minket a felhöalapú számítástechnika? A válasz nem ... ez csak egy bérleti rendszer."

Adatgyüjtésünk során nem találtunk pontos bizonyítékot arra vonatkozóan, hogy mikor vetődött fel a felső vezetésben a felhőtechnológia mint új iparág, ahova érdemes belépni. Valószínűsíthető, hogy a döntés 2009 és 2011 között történt, mert 2011-ben a vezérigazgató nyilvános beszédben már ezt állította:

"Mindenkinek van egy felhője, szükségünk van nekünk is egy felhöre."

Ettől kezdve a felső vezetés kommunikációja egyre inkább a felhőre összpontosított. Az éves jelentésében a „felhő" a 2010-es pénzügyi évben 0 említésről 112-re nőtt a 2011-es pénzügyi évben. A 2011-es pénzügyi év után az előző évhez képest folyamatosan nőtt (lásd az 1. ábrát). A 2017-es pénzügyi évben, a ,felhő" szót az éves jelentésben majdnem annyi alkalommal említették, mint a ,szoftver” szót, amely a vállalat alaptevékenysége (505 „felhő” és 536 ,szoftver”).

\section{1. ábra A vállalati éves jelentésekben a 'felhő' és a 'szoft- ver' szavak súlyozott gyakorisága
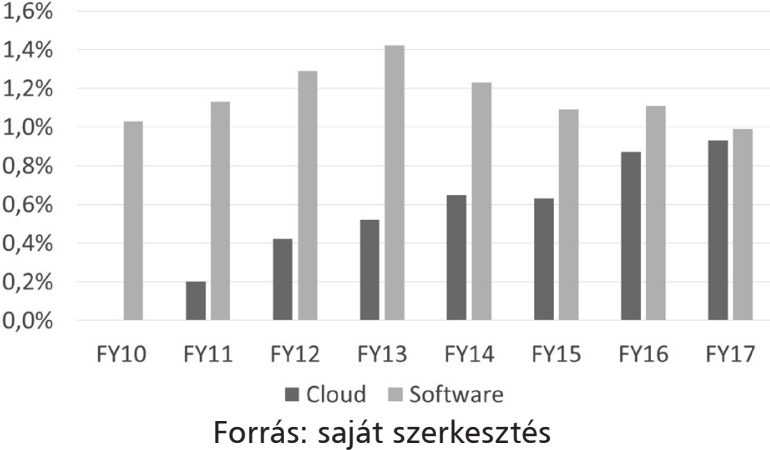

A felsővezetői kommunikációban az üzenet fokozatosan megváltozott, és 2012-ben a vállalat bejelentette az „iparág legszélesebb felhőstratégiáját”. De nemcsak a megújítási stratégia hangsúlyozása volt a cél, hanem annak lét- 
jogosultságának alátámasztása, amely egy külső kényszerre, veszélyre vezethető vissza. Például 2013-ban a társaság éves konferenciáján a vezérigazgató azt mondta, hogy:

"Az elörejelzések szerint 2025-re a vállalkozások által használt üzleti alkalmazások 80\%-a lesz a felhöben. Az eltolódás a felhö felé felgyorsul és elkerülhetetlen."

A „felhö” szó megnövekedett használata mellett más, a vezetési kommunikációban együtt járó szavak is mutatnak egy mintát. Belső kommunikációjában a felső vezetés elkezdte tisztázni a szervezet ,új” jövőjét, hogyan különbözik az a múlttól, és hogyan kell hozzájárulniuk a szervezeti tagoknak. Meghatározták a hajtóerőket, mint például az ügyfél igényeinek változása és a szervezeti elönyök. A helyzet meghatározása mellett - a feltörekvő új iparág, amely veszélyeztette a szervezet alaptevékenységét - a kommunikáció célja a szervezet egészére kiterjedő változások támogatása volt.

A kockázat szó a felhővel kapcsolatosan egyre gyakrabban szerepelt a vállalati jelentésekben. Például, amíg a felhőalapú üzleti tevékenységre való áttérés kockázata a 29. helyen szerepelt a vállalat 2011-es éves jelentésében, miszerint “a felhöszolgáltatás kínálatunk... nem lesz sikeres”; addig a 2012-es éves jelentésében ez a kockázat a 18. pozícióra lépett elő (29-ből), majd évröl-évre nagyobb jelentőséget kapott. A 2016-os éves jelentésében ez volt az első számú fenyegetés, és ez maradt a 2017-es évre is. Ekkor a kockázatot az éves jelentésben úgy határozták meg, mint “felhöstratégiánk... hátrányosan befolyásolhatja bevételeinket és nyereségességünket”. A folyamat elején a kockázatot nem lehetett teljes mértékben elöre látni, mivel túl sok félreértés volt. Ahogy a lehetőség kibontakozott és az átalakulás világossá vált, a kockázatok is egyértelmübbé váltak.

A kockázatok hangsúlyozása mellett („,muszáj meglépnünk”), ugyanakkor az „urai vagyunk a helyzetnek” utalásokkal a kommunikáció célja egyértelmüen a konszenzus és a szervezeti támogatás megnyerése volt. Ez nemcsak segítette a munkatársak mobilizálását és vállalati identitásának átalakítását, de csökkentette a szervezeti tagok bevonásra vonatkozó igényét is.

\section{A középvezetők szerepe a megújulási út során}

A vállalat stratégiai megújulása a fókuszált vállalattól egy kettős képességű szervezetig szándékos, felülről lefelé irányuló kezdeményezés volt. A felső vezetés egyik tagja így emlékezett vissza:

"Ez az átalakulás modelljének tudatos megválasztása volt. Nincs konszenzus, felülröl lefelé történik a döntéshozatal. És ez müködhet."

A frontvonal és a középvezetés bevonása a stratégia végrehajtására korlátozódott. Egy középvezető interjúalany így kommentálta:

"Ez egy határozottan kiadott feladat volt. Nem volt választásunk. Azt mondták, ez a tervszámod a felhőre, ezt csináld. Minden olyan kérést, mint a "hadd beszéljem meg az ügyfelemmel”, „,hadd lássam mi az elörelátható bevételem" - figyelmen kivül hagytak. Az embereknek csak azt mondták, hogy „csak csináld”. Ez kemény volt, mert az mellözött minden vitát arról, hogy helyes dolog volt-e vagy sem."
Nyilvánvaló volt, hogy a középvezetők csak passzív szerepet kaptak a stratégiai kijelölésében. Az egyik középvezető interjúalany megjegyezte, hogy nem is volt kísérlet a döntéshozatal decentralizálására:

"A stratégiát a központban határozták meg, és kiterjesztették a teljes vállalatra. Ez világos... Vannak olyan döntések, amelyek valóban csak a vezérigazgatói szinten és talán egy szinttel lejjebb történnek. Nem hiszem, hogy a nálunk [a vállalatnál] ezen szint alatt sok vita zajlott. Nekünk ez tetszhet, vagy sem, de ez így van. És összességében ez egészen jól müködik."

A limitált információ és a vita hiánya ellenére az alacsonyabb beosztású munkatársak - beleértve a középvezetést is - elfogadták passzív szerepüket és korlátozott befolyásukat a stratégia kialakítását illetően. A felső vezetők véleménye dominált, és az általános konszenzus az volt, hogy „,menjünk az áramlattal”. Az egyének ezért arra törekedtek, hogy saját céljaikat elérjék. A középvezetői interjúalanyok jelezték, hogy ha nehézségekkel találkoztak (pl. nem érték el a kitüzött bevételi célokat), úgy érezték, hogy „maguknak kell megoldani”.

Mások megerősítették, hogy míg a stratégia megfogalmazása felülről lefelé történt, a középvezetőknek volt némi szabadsága a végrehajtásban:

"Minden szinten léteznek különbözö stratégiai tevékenységek. Senki nem mondja meg pontosan, hogyan menjek a piacra a saját területemen. Senki sem mondja el nekem, hogyan inspirálhatom a csapatomat, és hogyan vigyem a megoldásokat a piacra... A stratégia végrehajtásával kapcsolatban sok a lehetöség egyéni döntésekre a vállalatnál, ugyanakkor nagyon világos, hogy az alapvetó döntéseket nem demokratikusan hozzák meg el."

A központosított irányítás-ellenőrzési rendszer a felső vezetést időben tájékoztatta mindenről, ami a szervezetben történt. A felső vezetés tehát képes volt az új stratégiát minimális szervezeti tehetetlenséggel és ellenállással érvényesíteni. Például, amikor az értékesítési kompenzáció megváltoztatásáról döntött a felső vezetés, a felhő értékesítésének motivációjának növelése érdekében, a globális megvalósítás nagyon gyors volt. A kereskedőknek fizetett jutalék kiszámítása minden értékesítési munkatársnak globálisan megváltozott anélkül, hogy aktív középvezetői bevonás során egyeztették volna. Ahogy egy középvezető magyarázta:

“Ez nem olyan cég, amely jutalmazza a felelösség megosztását, vagy a hozzájárulás nagyon széles körét. Mindannyiunknak nagyon világos céljai, nagyon világos feladatai vannak és nagyon világos mérési rendszer van. A jó dolog az, hogy mindez nagyon világos és egyértelmü."

A felső vezetés rövid távon is nyomon tudta követni az új kompenzációs rendszer hatását az értékesítési csatornára. Amikor beavatkozásra volt szükség, tovább módosították a pénzügyi ösztönzőket. Ezeknek a változásoknak a végrehajtása ismét gyors és zökkenőmentes volt, újfent nélkülözve a szervezet egészére kiterjedő megbeszélést vagy a középvezetői részvételt a döntéshozatalban.

A top-down megközelítés egy másik példája a termékmarketingben bevezetett változások voltak. A felhőtermékek, mind az új célfogyasztók, a kkv-k különböző üzeneteket és kommunikációt igényeltek. Az új marketingüzeneteket és 
-tevékenységeket felülről határozták meg, a helyi szervezetek nagyon kevés befolyást gyakoroltak ezen üzenetek tartalmára. A marketingüzenetek által generált új üzleti lehetőségek (sales pipeline) növekedését szorosan nyomon követték a belső kontrollrendszereken keresztül. Ez a valós idejü piaci hírszerzés lehetővé tette a felső vezetők számára például annak követését, hogy az új marketingüzenetekre hogyan reagálnak az ügyfelek, és szükség esetén szinte valós-időben módosíthatták azokat, így csökkentve az értékesítési szervezettől kapott visszajelzésektől való függést (Keszey, 2018).

A felhő egy új piac volt, így a felhőalapú termékek árképzése kihívást jelentett. A felső vezetők nyomon követték a megnyert és elvesztett üzletek arányát és az elvesztett üzletek okait az SI rendszeren keresztül, és az információk alapján rendszeresen kiigazították az árakat. Szükség esetén korlátozott időre további kedvezményeket is bevezettek annak érdekében, hogy versenyképesek legyenek az árak.

\section{Eredmények: Dinamikus környezetben kontrollált stratégiai megújulás}

Mind a dokumentáció, mind az interjúk elemzése megerősítette, hogy a stratégiai megújulás felhő megoldásokra merész lépés volt, ami egy technikai váltásnál sokkal több kihívást hordozott magában. Ugyanakkor az eredmények rámutattak arra, hogy a fejlett üzletiintelligencia-rendszerek lehetővé tették a nagyvállalatban, hogy egy felülröl lefelé, szorosan ellenőrzött folyamat során kettős képességűvé váljon. Az adatvezérelt és automatizált visszacsatolási rendszer biztosította, hogy a felső vezetés gyorsan reagáljon és tanuljon, így kevesebb erőfeszítésre volt szükség a változás megvalósításához és megszilárdításához.

Korábbi kutatások (pl. Volberda et al., 2001) azt sugallják, hogy a közép- és frontvonal vezetők bevonása elengedhetetlen a turbulens, nagy bizonytalansággal küzdő iparágakban a szervezeti megújításhoz. Lehetőséget kell biztosítani a középvezetök aktív részvételére, hogy ezáltal a szervezeti ellenállás kibontakozását megelőzze s a vezetés hozzáférjen a szükséges információkhoz, amelyek az alkalmazkodáshoz elengedhetetlenek. Jelen tanulmányban vizsgált szervezet esetében azonban a stratégiai megújulást teljes mértékben felsővezetői szint vezényelte le, a középvezetői bevonás nem valósult meg.

Először is, a felső vezetés nem törekedett a decentralizált döntéshozatalra. Sőt, a középvezetők gyakorlatilag ki voltak zárva a stratégiai döntésekből, szerepük meglehetősen paszszív volt. Az interjúk megerösítették, hogy a felülröl lefelé történő változás nehéz volt a középvezetés számára, különösen azért, mert nem volt lehetőség a megbeszélésre vagy tárgyalásra annak tartalmáról és hatóköréröl. Ez a megoldás eltér a munkatársak bevonásának trendjétől (Bácsi, 2017).

Néhány, korábbi tanulmányok szintén ellentmondásos eredményekre jutott, ami szintén az egyes szervezetekben alkalmazott vezetői irányítási rendszerek közötti különbségekre vezethető vissza. Hasonlóan jelen kutatás eredményeihez, Demeter és Losonci (2019) tudástranszfert vizsgálva arra a következtetésre jutott, hogy egyrészt a szofisztikált támogató rendszerek lehetővé teszik mind az explicit, mind a tacit tudás átadását földrajzilag széttagolt szervezetekben, másrészt felső vezetők a meghatározók a változási folyamat során.

A középvezetői szint bevonásának szükségességét a felső vezetés a vizsgált vállalat esetében azonban a fejlett döntéstámogató rendszerrel egyidejüleg egy gondosan megtervezett szervezeti kommunikáció indult el, amely a stratégiai megújulás hajtóerejét egy külső kényszerrel azonosította. A kollektív reakció a változásokra következésképp egy a felsővezetői irányítást elfogadó, a stratégia létjogosultságát nem vitató középvetés volt. Eredményeink ezért ellentmondanak annak a feltételezésnek is, hogy egy irányított megújítási út kevésbé alkalmas a dinamikus, gyorsan változó környezetben müködö cégek számára.

Ez a megújulási út tehát egy hibrid formája volt Volberda és szerzőtársai (2001) által javasolt modell két lehetséges útjának (irányított és transzformatív), amit kontrollált megújulási útnak neveztünk el (2. táblázat).

2. táblázat Több egységben működő vállalatok megújulási útjainak típusai

\begin{tabular}{|l|c|c|}
\hline & $\begin{array}{c}\text { A felső vezetés } \\
\text { passzív a } \\
\text { környezet } \\
\text { szempontjából }\end{array}$ & $\begin{array}{c}\text { A felső vezetés } \\
\text { aktív a környezet } \\
\text { szempontjából }\end{array}$ \\
\hline $\begin{array}{l}\text { A frontvonal és a } \\
\text { középvezetök passzivak } \\
\text { (stabil verseny) }\end{array}$ & $\begin{array}{c}\text { Felbukkanó } \\
\text { megújulás }\end{array}$ & $\begin{array}{c}\text { Irányított } \\
\text { megújítás }\end{array}$ \\
\hline $\begin{array}{l}\text { A frontvonal és a } \\
\text { középvezetők passzívak, } \\
\text { de a támogatási } \\
\text { rendszerek aktívak } \\
\text { (extrém verseny) }\end{array}$ & - & $\begin{array}{c}\text { Kontrollált } \\
\text { megújitás }\end{array}$ \\
\hline $\begin{array}{l}\text { A frontvonal és a } \\
\text { középvezetők aktívak } \\
\text { (extrém verseny) }\end{array}$ & $\begin{array}{l}\text { Elősegített } \\
\text { megújulás }\end{array}$ & $\begin{array}{c}\text { Transzformációs } \\
\text { megújulás }\end{array}$ \\
\hline
\end{tabular}

Forrás: Volberda et al. (2001, p. 163) (kiterjesztése dőlt betűvel jelölve)

A kontrollált megújulás során az egyik irányból a másikba való átmenetet egy szűk felsővezetői csoport vezérli, még több tízezer alkalmazottal rendelkező vállalat esetén is. Ennek a megújulási útnak a fö előnye, hogy a szervezet teljes mértékben megvalósíthatja a magasan centralizált formális tervezés és ellenőrzés minden előnyét, miközben rugalmas és kettős képességü lesz. Ez pedig végeredményben új versenyelönyt jelenthet.

Prahalad és Hamel (1990) szintén hasonló következtetésre jutottak, s azzal érveltek, hogy a stratégiai megújulás a vezérigazgató vagy a vállalati menedzsment stratégiai szándékától függ, és szükségszerü, hogy a felső vezetés kifinomult elörejelzéssel rendelkezzen az iparági változások tekintetében.

Az esettanulmány szintén megerősíti a fenyegetés-merevség tézist. A biztonsági kockázatok (cf. Simay \& Gáti, 2017) kommunikálásával az alkalmazottak által észlelt külső környezet fenyegetése, a piaci pozíció elvesztésének súlyossága sokkal meghatározóbb lett. A külső veszélyhelyzetet ezért a felső vezetők ki tudták használni a szervezeti tagok bevonásra való igényének csökkentésére. A külső fenyegetettség hangsúlyos kommunikálásával magyarázható a középvezetők passzivitása. Ahelyett, hogy részvételt követeltek volna, konszenzust 
kerestek, és ezzel támogatták a felső vezetés politikáját és stratégiáját. Ennek eredményeképpen a felső vezetők hatalma a szervezeti tagok befolyásolására sokkal nagyobb lett.

\section{A kutatás korlátai és jövőbeli kutatási irányok}

Vizsgálataink egyetlen esettanulmányra korlátozódtak, így eredményei nem széles körben általánosíthatók. Az általánosíthatóság korlátja az is, hogy az esettanulmányban szereplő vállalatnak nem a teljes szervezetét vizsgáltuk meg; például a termékfejlesztés közép- és felső vezetőivel nem készültek interjúk. További kutatás szükséges azon külső és belső tényezők pontos azonosítására, melyek lehetővé tették a vállalat számára 'kontrollált megújulást'. Ezek feltárása hasznos lehet más vállalatok felső vezetői számára, akik hasonló megújulási utat terveznek.

\section{Felhasznált irodalom:}

Agarwal, R., \& Helfat, C. E. (2009). Strategic renewal of organizations. Organization Science, 20(2), 281-293. https://doi.org/10.1287/orsc.1090.0423

Andriopoulos, C., \& Lewis, M. W. (2009). Exploitation-exploration tensions and organizational ambidexterity: Managing paradoxes of innovation. Organization science, 20(4), 696-717. https://doi.org/10.1287/orsc.1080.0406

Bácsi, K. (2017). Miért és mikor jó a bevonás?-érvek munkáltatói és munkavállalói oldalon. Vezetéstudomány/Budapest Management Review, 48(8-9), 13-21. https://doi.org/10.14267/VEZTUD.2017.09.02

Balogun, J., \& Johnson, G. (2004). Organizational restructuring and middle manager sensemaking. Academy of Management Journal, 47(4), 523-549. https://doi.org/10.2307/20159600

Barney, J. A. Y., \& Felin, T. (2013). What are microfoundations? Academy of Management Perspectives, 27(2), 138-155. https://doi.org/10.5465/amp.2012.0107

Beer, M., \& Nohria, N. (Eds.). (2000). Breaking the code of change (Vol. 78, No. 3, pp. 133-141). Boston, MA: Harvard Business School Press.

Benner, M. \& Tushman, M., (2003). Exploitation, exploration, and process management: The productivity dilemma revisited. Academy of Management Review, 28(2), 238-256. https://doi.org/10.5465/amr.2003.9416096

Birkinshaw, J., \& Gupta, K. (2013). Clarifying the distinctive contribution of ambidexterity to the field of organization studies. Academy of Management Perspectives, 27(4), 287-298. https://doi.org/10.5465/amp.2012.0167

Birkinshaw, J. \& Gibson, C., (2004). Building ambidexterity into an organisation. MIT Sloan Management Review, 45(4), 47-55.

Bower, J. L. \& Christensen, C. M. (1996). Disruptive technologies: Catching the wave. The Journal of Product Innovation Management, 1(13), 75-76. https://doi. org/10.1016/0737-6782(96)81091-5

Bögel, Gy. (2008). A schumpeteri ,teremtő rombolás "módjai az infokommunikációs iparban. Közgazdasági Szemle/Economic Review, 55.

Burgelman, R. A. (1983). A process model of internal corporate venturing in the diversified major firm. $A d$ ministrative Science Quarterly, 223-244. https://doi. org/10.2307/2392619
Burgelman, R. A., Floyd, S. W., Laamanen, T., Mantere, S., Vaara, E., \& Whittington, R. (2018). Strategy processes and practices: Dialogues and intersections. Strategic Management Journal, 39(3), 531-558. https://doi.org/10.1002/smj.2741

Burgers, H. \& Jansen, J. J. (2008). Organizational ambidexterity and corporate entrepreneurship: The differential effects on venturing, innovation and renewal processes. Frontiers of Entrepreneurship Research, 28(19), 2.

Burgess, N., Strauss, K., Currie, G., \& Wood, G. (2015). Organizational ambidexterity and the hybrid middle manager: The case of patient safety in UK hospitals. Human Resource Management, 54(S1), s87-s109. https://doi.org/10.1002/hrm.21725

Cembrero, D. \& Sáenz, J. (2018). Performance outcomes of interaction, balance, and alignment between exploration and exploitation in the technological innovation domain. International Journal of Business Innovation and Research, 15(1), 14-33. https://doi.org/10.1504/IJBIR.2018.10009018

Chang, Y. Y. \& Hughes, M. (2012). Drivers of innovation ambidexterity in small-to medium-sized firms. European Management Journal, 30(1), 1-17. https:// doi.org/10.1016/j.emj.2011.08.003

Christensen, C. M., \& Overdorf, M. (2000). Meeting the challenge of disruptive change. Harvard Business Review, 78(2), 66-77.

Christensen, C. M., Raynor, M. E., \& McDonald, R. (2015). What is disruptive innovation. Harvard Business Review, 93(12), 44-53.

Cuervo Cazurra, A., Mudambi, R., Pedersen, T., \& Piscitello, L. (2017). Research methodology in global strategy research. Global Strategy Journal, 7(3), 233-240. https://doi.org/10.1002/gsj.1164

Csedő, Z., Zavarkó, M., \& Sára, Z. (2019). Tudásmenedzsment és stratégiai kettős képesség-Felsővezetői döntések elemzése az innovációs stratégia megvalósítása során. Vezetéstudomány/Budapest Management Review, 50(3), 36-49. https://doi.org/10.14267/VEZTUD.2019.03.04

D'Aveni, R. A., \& MacMillan, I. C. (1990). Crisis and the content of managerial communications: A study of the focus of attention of top managers in surviving and failing firms. Administrative Science Quarterly, 634-657. https://doi.org/10.2307/2393512

Demeter, K. \& Losonci, D. (2019). Transferring lean knowledge within multinational networks. Production Planning \& Control, 30(2-3), 211-224. https://doi.org/1 0.1080/09537287.2018.1534272

Demeter, K., Losonci, D., Szász, L., \& Rácz, B. G. (2018). Assessing Industry 4.0 readiness: a multi-country industry level analysis.

Duncan, R. B. (1976). The ambidextrous organization: Designing dual structures for innovation. The Management of Organization, 1(1), 167-188.

Dutton, J. E. \& Ashford, S. J. (1993). Selling issues to top management. Academy of Management Review, 18(3), 397-428. https://doi.org/10.5465/amr.1993.9309035145

Floyd, S. W. \& Lane, P. J. (2000). Strategizing throughout the organization: Managing role conflict in strategic renewal. Academy of Management Review, 25(1), 154177. https://doi.org/10.5465/amr.2000.2791608 
Floyd, S. W., \& Wooldridge, B. (1999). Knowledge creation and social networks in corporate entrepreneurship: The renewal of organizational capability. Entrepreneurship Theory and Practice, 23(3), 123-144. https://doi. org/10.1177/104225879902300308

Forbes, D. P. \& Kirsch, D. A. (2011). The study of emerging industries: Recognizing and responding to some central problems. Journal of Business Venturing, 26(5), 589602. https://doi.org/10.1016/j.jbusvent.2010.01.004

Füzes, P., Gódor, Z., \& Szabó, Z. R. (2018). Szabadulás a kiaknázási csapdából a digitális jövő alakításával. Hogyan irányítható az iparági változás egy felhőalapú szolgáltatásra épülő kiaknázási és felderítési tevékenységgel? Vezetéstudomány/Budapest Management Review, 49(1), 54-64. https://doi.org/10.14267/VEZTUD.2018.01.06

Gelei, A. \& Jámbor, Z. (2018). Globális vállalatok belső struktúrájának alakítása a beszerzés és a termékfejlesztés kapcsolódó tevékenységeinek tükrében. Vezetéstudomány/Budapest Management Review, 49(3), 52-63. https://doi.org/10.14267/VEZTUD.2018.03.06

Gibson, C. B. \& Birkinshaw, J. (2004). The antecedents, consequences, and mediating role of organizational ambidexterity. Academy of Management Journal, 47(2), 209-226. tttps://doi.org/10.2307/20159573

Graham, J. W. (1986). Principled organizational dissent: A theoretical essay. Research in Organizational Behavior.

Gulati, R. \& Puranam, P. (2009). Renewal through reorganization: The value of inconsistencies between formal and informal organization. Organization Science, 20(2), 422-440. https://doi.org/10.1287/orsc.1090.0421

Guth, W. D., \& Ginsberg, A. (1990). Guest editors' introduction: Corporate entrepreneurship. Strategic Management Journal, 5-15.

Guth, W. D. \& MacMillan, I. C. (1986). Strategy implementation versus middle management self-interest. Strategic Management Journal, 7(4), 313-327. https:// doi.org/10.1002/smj.4250070403

Hambrick, D. C. \& Mason, P. A. (1984). Upper echelons: The organization as a reflection of its top managers. Academy of Management Review, 9(2), 193-206. https://doi.org/10.5465/amr.1984.4277628

Hamel, G. (1990). The core competence of the corporation. Harvard Business Review, 68(3), 79-91.

Harrigan, K. R. (1980). Strategy formulation in declining industries. Academy of Management Review, 5(4), 599-604. https://doi.org/10.5465/amr.1980.4288965

Holsti, O. R. (1969). Content analysis for the social sciences and humanities. Reading. MA: Addison-Wesley (content analysis). https://doi.org/10.1016/S08839026(00)00059-8

Hornsby, J. S., Kuratko, D. F., \& Zahra, S. A. (2002). Middle managers' perception of the internal environment for corporate entrepreneurship: assessing a measurement scale. Journal of Business Venturing, 17(3), 253273. https://doi.org/10.1016/S0883-9026(00)00059-8

Hortoványi, L. (2010). Vállalkozó vezetés Magyarországon. Vezetéstudomány/Budapest Management Review, 41(4), 21-31.
Horváth, A. \& Papp, I. (2015). Léteznek jövőbeli sikerességét meghatározó tényezők a KKV- szektorban? Journal of Central European Green Innovation, 3(1063-2016-86206), 47-58.

Hughes, M., Filser, M., Harms, R., Kraus, S., Chang, M. L., \& Cheng, C. F. (2018). Family firm configurations for high performance: The role of entrepreneurship and ambidexterity. British Journal of Management, 29(4), 595-612. https://doi.org/10.1111/1467-8551.12263

Jansen, K. J. (2004). From persistence to pursuit: A longitudinal examination of momentum during the early stages of strategic change. Organization Science, 15(3), 276-294. https://doi.org/10.1287/orsc.1040.0064

Jarzabkowski, P., Balogun, J., \& Seidl, D. (2007). Strategizing: The challenges of a practice perspective. Human Relations, 60(1), 5-27. https://doi. org/10.1177/0018726707075703

Jones, S., Irani, Z., Sivarajah, U., \& Love, P. E. (2017). Risks and rewards of cloud computing in the UK public sector: A reflection on three Organisational case studies. Information Systems Frontiers, 1-24. https:// doi.org/10.1007/s10796-017-9756-0

Junni, P., Sarala, R. M., Taras, V., \& Tarba, S. Y. (2013). Organizational ambidexterity and performance: A meta-analysis. Academy of Management Perspectives, 27(4), 299-312.

Junni, P., Sarala, R. M., Tarba, S., Liu, Y., Cooper, C., Junni, P., ... \& Liu, Y. (2015). The role of human resource and organizational factors in ambidexterity. Human Resource Management, S, 54. https://doi.org/10.5465/ ambpp.2015.10372abstract

Keszey, T. (2018). Bizalom és vezetői információfelhasználás: a hatalom moderáló hatása. Statisztikai Szemle, 96(2), 164-181. DOI 10.20311/stat2018.02.hu0164

Khandwalla, P. N. (1972). The effect of different types of competition on the use of management controls. Journal of Accounting Research, 275-285. https://doi. org/10.2307/2490009

Kim, B., Kim, E., \& Foss, N. J. (2016). Balancing absorptive capacity and inbound open innovation for sustained innovative performance: An attention-based view. European Management Journal, 34(1), 80-90. https://doi.org/10.1016/j.emj.2015.10.002

Kiss, J. (2005). Az innováció és a technológiai fejlödés elmélete az evolucionista közgazdságtanban. 59. sz. Mủhelytanulmány. Mühelytanulmányok. Budapest: Vállalatgazdaságtan Intézet.

Kotter, J. P. (1995). Leading change: Why transformation efforts fail. Boston, Mass.: Harvard Business School Press.

Kuckertz, A. \& Kohtamaki, M. (2010). The fast eat the slowthe impact of strategy and innovation timing on the success of technology-oriented ventures. International Journal of Technology Management, 52(1/2), 175-188. https://doi.org/10.1504/IJTM.2010.035861

Liu, L. \& Leitner, D. (2012). Simultaneous pursuit of innovation and efficiency in complex engineering projects: A study of the antecedents and impacts of ambidexterity in project teams. Project Management Journal, 43(6), 97-110. https://doi.org/10.1002/pmj.21301 
Lubatkin, M. H., Simsek, Z., Ling, Y., \& Veiga, J. F. (2006). Ambidexterity and performance in small-to mediumsized firms: The pivotal role of top management team behavioral integration. Journal of Management, 32(5), 646-672. https://doi.org/10.1177/0149206306290712

March, J. G. (1991). Exploration and exploitation in organizational learning. Organization Science, 2(1), 71-87. https://doi.org/10.1287/orsc.2.1.71

Marston, S., Li, Z., Bandyopadhyay, S., Zhang, J., \& Ghalsasi, A. (2011). Cloud computing-The business perspective. Decision Support Systems, 51(1), 176-189. https://doi.org/10.1016/j.dss.2010.12.006

McCarthy, I. P., \& Gordon, B. R. (2011). Achieving contextual ambidexterity in R\&D organizations: a management control system approach. R\&D Management, 41(3), 240258. https://doi.org/10.1111/j.1467-9310.2011.00642.x

Mell, P. \& Grace, T. (2011). The NIST definition of cloud computing. https://doi.org/10.6028/NIST.SP.800-145

Meyer, C. (1998). Relentless growth: how Silicon Valley innovation strategies can work in your business. New York: Simon and Schuster.

Müller, J. \& Kunisch, S. (2018). Central perspectives and debates in strategic change research. International Journal of Management Reviews, 20(2), 457-482. https://doi.org/10.1111/ijmr.12141

Nigam, A., \& Ocasio, W. (2010). Event attention, environmental sensemaking, and change in institutional logics: An inductive analysis of the effects of public attention to Clinton's health care reform initiative. Organization Science, 21(4), 823-841. https://doi. org/10.1287/orsc.1090.0490

Nonaka, I. (1994). A dynamic theory of organizational knowledge creation. Organization Science, 5(1), 14-37. https://doi.org/10.1287/orsc.5.1.14

Ocasio, W. (1997). Towards an attention-based view of the firm. Strategic Management Journal, 18(S1), 187-206. https://doi.org/10.1002/(SICI)1097-0266(199707)18

Ocasio, W. (2011). Attention to attention. Organization Science, 22(5), 1286-1296. https://doi.org/10.1287/ orsc. 1100.0602

Ocasio, W. \& Joseph, J. (2005). An attention-based theory of strategy formulation: Linking micro-and macroperspectives in strategy processes. In Strategy Process (pp. 39-61). Emerald Group Publishing Limited. https://doi.org/10.1016/S0742-3322(05)22002-8

Ocasio, W., Laamen, T., \& Vaara, E. (2018). Communication and attention dynamics: An attention-based view of strategic change. Strategic Management Journal, 39, 155-167. https://doi.org/10.1002/smj.2702

O'Reilly III, C. A., \& Tushman, M. L. (2013). Organizational ambidexterity: Past, present, and future. Academy of Management Perspectives, 27(4), 324-338. https://doi. org/10.5465/amp.2013.0025

Patel, P. C., Messersmith, J. G., \& Lepak, D. P. (2013). Walking the tightrope: An assessment of the relationship between high-performance work systems and organizational ambidexterity. Academy of Management Journal, 56(5), 1420-1442. https://doi.org/10.5465/ amj.2011.0255
Raes, A. M., Heijltjes, M. G., Glunk, U., \& Roe, R. A. (2011). The interface of the top management team and middle managers: A process model. Academy of Management Review, 36(1), 102-126. https://doi.org/10.5465/amr.2009.0088

Raisch, S. (2008). Balanced structures: designing organizations for profitable growth. Long Range Planning, 41(5), 483-508. https://doi.org/10.1016/j. lrp.2008.06.004

Raisch, S. \& Birkinshaw, J. (2008). Organizational ambidexterity: Antecedents, outcomes, and moderators. Journal of Management, 34(3), 375-409. https://doi. org/10.1177/0149206308316058

Ren, C. R. \& Guo, C. (2011). Middle managers' strategic role in the corporate entrepreneurial process: Attentionbased effects. Journal of Management, 37(6), 15861610. https://doi.org/10.1177/0149206310397769

Ross, L. \& Nisbett, R. E. (2011). The person and the situation: Perspectives of social psychology. Pinter \& Martin Publishers.

Rouhani, S., Ghazanfari, M., \& Jafari, M. (2012). Evaluation model of business intelligence for enterprise systems using fuzzy TOPSIS. Expert Systems with Applications, 39(3), 3764-3771. https://doi.org/10.1016/j.eswa.2011.09.074

Shane, S., \& Venkataraman, S. (2000). The promise of entrepreneurship as a field of research. Academy of Management Review, 25(1), 217-226.

Sidhu, J. S., Commandeur, H. R., \& Volberda, H. W. (2007). The multifaceted nature of exploration and exploitation: Value of supply, demand, and spatial search for innovation. Organization Science, 18(1), 2038. https://doi.org/10.1287/orsc.1060.0212

Simay, A. E., \& Gáti, M. (2017). A fogyasztói jelenlét és a nyilvánosság iránti attitüdök vizsgálata a mobil és közösségi médiában. Vezetéstudomány/Budapest Management Review, 48(1), 61-69. https://doi.org/10.14267/ VEZTUD.2017.01.06

Simons, R. (1987). Accounting control systems and business strategy: an empirical analysis. Accounting, Organizations and Society, 12(4), 357-374. https://oi. org/10.1016/0361-3682(87)90024-9

Simons, R. (1994). How new top managers use control systems as levers of strategic renewal. Strategic Management Journal, 15(3), 169-189. https://doi.org/10.1002/ smj.4250150301

Sine, W. D., \& David, R. J. (2003). Environmental jolts, institutional change, and the creation of entrepreneurial opportunity in the US electric power industry. Research Policy, 32(2), 185-207. https://doi. org/10.1016/S0048-7333(02)00096-3

Spilák, V., \& Kosztyán, Z. T. (2019). Szervezeti kultúra, vezetői szerepek, az információbiztonság és a felhőalapú megoldások kapcsolata. Vezetéstudomány/ Budapest Management Review, 50(7-8), 70-87. DOI 10.14267/VEZTUD.2019.07.07

STATISTA (2018). Public cloud market revenue worldwide from 2012 to 2027 (in billion U.S. dollars) [Online]. Available: https://www.statista.com/statistics/477702/publiccloud-vendor-revenue-forecast/ [Accessed December 23. 2018]. 
Staw, B. M., Sandelands, L. E., \& Dutton, J. E. (1981). Threat rigidity effects in organizational behavior: A multilevel analysis. Administrative Science Quarterly, 501-524. https://doi.org/10.2307/2392337

Stopford, J. M. \& Baden Fuller, C. W. (1994). Creating corporate entrepreneurship. Strategic Management Journal, 15(7), 521-536. https://doi.org/10.1002/smj.4250150703

Sultan, N. (2013). Knowledge management in the age of cloud computing and Web 2.0: Experiencing the power of disruptive innovations. International Journal of Information Management, 33(1), 160-165. https://oi. org/10.1016/j.ijinfomgt.2012.08.006

Sultan, N. \& van de Bunt-Kokhuis, S. (2012). Organisational culture and cloud computing: coping with a disruptive innovation. Technology Analysis \& Strategic Management, 24(2), 167-179. https://doi.org/10.1080/09537325.2012.647644

Szabó, K. (2017). Institutional entrepreneurship: Agents' ability and activity for building up new institutions by combining existing elements. Society and Economy. In Central and Eastern Europe. Journal of the Corvinus University of Budapest, 39(3), 359-383. https://doi.org/10.1556/204.2017.39.3.5

Szukits, Á. (2017). Management control system design: The effect of tools in use on the information provided. Vezetéstudomány/Budapest Management Review, 48(5), 2-13. DOI 10.14267/VEZTUD.2017.05.01

Taylor, A. \& Helfat, C. E. (2009). Organizational linkages for surviving technological change: Complementary assets, middle management, and ambidexterity. Organization Science, 20(4), 718-739. https://doi.org/10.1287/orsc.1090.0429

Teece, D. J., Pisano, G., \& Shuen, A. (1997). Dynamic capabilities and strategic management. Strategic Management Journal, 18(7), 509-533. https://doi. org/10.1002/(SICI)1097-0266(199708)18

Tuggle, C. S., Sirmon, D. G., Reutzel, C. R., \& Bierman, L. (2010). Commanding board of director attention: investigating how organizational performance and CEO duality affect board members' attention to monitoring. Strategic Management Journal, 31(9), 946-968. https://doi.org/10.1002/smj.847

Turban, E., Sharda, R., \& Delen, D. (2014). Business intelligence and analytics: systems for decision support. Harlow: Pearson Higher Education.

Turner, N., Swart, J., \& Maylor, H. (2013). Mechanisms for managing ambidexterity: A review and research agenda. International Journal of Management Reviews, 15(3), 317-332. https://doi.org/10.1111/j.1468-2370.2012.00343.x

Uyterhoeven, H. E. (1972). General managers in middle. Harvard Business Review, 50(2).

Van Looy, B., Martens, T., \& Debackere, K. (2005). Organizing for continuous innovation: On the sustainability of ambidextrous organizations. Creativity and
Innovation Management, 14(3), 208-221. https://doi. org/10.1111/j.1467-8691.2005.00341.x

Venkataraman, S. (1997). The distinctive domain of entrepreneurship research. Advances in Entrepreneurship, Firm Emergence and Growth, 3(1), 119-138.

Volberda, H. (2017). Comments on'Mastering strategic renewal: Mobilising renewal journeys in multi-unit firms'. Long Range Planning, 50(1), 44-47. https://doi. org/10.1016/j.lrp.2016.12.002

Volberda, H. W., Baden-Fuller, C., \& Van Den Bosch, F. A. (2001). Mastering strategic renewal: Mobilising renewal journeys in multi-unit firms. Long Range Planning, 34(2), 159-178. https://doi.org/10.1016/S0024-6301(01)00032-2

Vuori, T. O., \& Huy, Q. N. (2016). Distributed attention and shared emotions in the innovation process: How Nokia lost the smartphone battle. Administrative Science Quarterly, 61(1), 9-51. https://doi. org/10.1177/0001839215606951

Wei, Z., Zhao, J., \& Zhang, C. (2014). Organizational ambidexterity, market orientation, and firm performance. Journal of Engineering and Technology Management, 33, 134-153. https://doi.org/10.1016/j.jengtecman.2014.06.001

Wickenberg, J. (2013). Trade-offs between efficiency and legitimacy when implementing a large change program at the middle management level. In Presented at the 8th Colloquium On Organisational Change \& Development. Gent, Belgium, September 12 and 13, 2013.

Wooldridge, B., Schmid, T., \& Floyd, S. W. (2008). The middle management perspective on strategy process: Contributions, synthesis, and future research. Journal of Management, 34(6), 1190-1221. https://doi. org/10.1177/0149206308324326

Yadav, M. S., Prabhu, J. C., \& Chandy, R. K. (2007). Managing the future: $\mathrm{CEO}$ attention and innovation outcomes. Journal of Marketing, 71(4), 84-101. https://doi. org/10.1509/jmkg.71.4.84

Yu, J., Engleman, R. M., \& Van de Ven, A. H. (2005). The integration journey: An attention-based view of the merger and acquisition integration process. Organization Studies, 26(10), 1501-1528. https://doi. org $/ 10.1177 / 0170840605057071$

Zimmermann, A., Raisch, S., \& Birkinshaw, J. (2015). How is ambidexterity initiated? The emergent charter definition process. Organization Science, 26(4), 11191139. https://doi.org/10.1287/orsc.2015.0971

Zimmermann, A., Raisch, S., \& Cardinal, L. B. (2018). Managing persistent tensions on the frontline: A configurational perspective on ambidexterity. Journal of Management Studies, 55(5), 739-769. https://doi. org/10.1111/joms.12311 